\title{
THE SOCIAL ECONOMIC LIFE OF BANYUMAS RURAL COMMUNITY UNTIL THE XX CENTURY
}

\author{
Tanto Sukardi ${ }^{1}$
}

\begin{abstract}
The reconstruction of social economic history in Banyumas in 1830-1900, has purpose to study the various factors which affect the social change in that region. This research uses theoretical frame, connected with the social change theory and the applicable method of history research through multidimensional approach, which related to the social and economic aspect. The historic research may be stated that the implementation of cultuurstelsel (enforcement planting or cultivation system) is the collaboration between West capitalism system with the traditional-feudalistic economy system, in order to exploitate the land and the workforce of the resident. The changes can be sectorial and partial, slow and non-comprehensive. In economic sector, the change is the distribution of money economy, which marked with the economy activities and the establishment of economy institution such as the credit service institution. While in the social sector, there is no new formation of social institution. However, some function dislocations in the society occur.
\end{abstract}

Key words: Social economic life, rural, and Banyumastime state."

\footnotetext{
${ }^{1}$ Tanto Sukardi is lecture of History Education of FKIP University of Muhammadiyah Purwokerto. For academic interest, the author can be contacted at e-mail address: tanto_sukardi@yahoo.com
} 


\section{Introduction}

The common tradition in Banyumas, in the evolution, has experienced the shifting process as the result of colonial interaction since the implementation of cultuurstelsel (1830). The bond of commons tradition, hierarchically, stranded with the noble tradition of palace (Surakarta) which at that time begin to vanish, due to the repressive colonial political policy. The detachment of palace control on commons tradition behavior in Banyumas, gave them freedom in searching their appropriate form. One of the interesting symptoms is the social change and the dislocation of their traditional values. However, some part of their rough identity, honestly and straightforward (blaka suta) are still attached on them (Pauwert, 1977: 148). Such identity is the distinctive mark and a tendency that affecting the development of rural life in Banyumas until today.

The study of the past rural life in Banyumas may increase the understanding of value on the history awareness for the young generation, it shall highlight two sides: 1) The awareness as psychology symptom, is related to the construction of past experience comprehension that indicated with the intensive selection of time perspective, so that a person is able to differentiate the past, present, and future dimension. This is marked with the ability to coherently construct the past accumulation in the memory or conscious. 2) The history awareness as historic symptom can be seen from someone ability to understand the spiritual monumental symbols such as the soul of the time, the spirit of the time, historic vision, and cultural value (Suryo, 1991: 5). In the journey of time, the comprehension of such cultural value change with the perspective transformation of society. This is the important part of historical research.

The study of history should be able to provide social reality learning. Therefore, the learning process focused on problem oriented. This can be achieving if student has been prepared and facilitated with the critical thinking ability. The problem oriented learning is the right tool to understand the social problem. In turn, the ability to understand such as social problem shall be transfered and use to solving other problem which is relevant to the life. Furthermore, the problem solving ability will increase the ability on analytical aspect and also can be used in various situations. In addition, generally, such learning may increase study motivation for student and society (Bell, 1978: 311).

\section{Demographic Condition}

Until180o,theJavanesehadcompletely depends their life on agriculture, while the economy still used the close system. During the 1800-1850, the total population with such way of life reached about 70\% (Peper, 1975: 14). The society in that condition tends to have high natality and density rate. According to Peper analysis (1975: 14$15)$, the rate of high natality reached $4 \%$ to $5 \%$ per year. While, the mortality rate was estimated around $2.25 \%$ to $2.50 \%$, so that the growth rate of Javanese people during the time was estimated $2.5 \%$ per year. This condition was supported by the report on reign of Raffles (1811-1816). In that report stated that the rice plantation center areas in Central Java had crowded population (Breman, 1971: 13).

If we notice, there is always the connection between population densities 
in one area with the production level. This mutual relation is the influence between agriculture productions with the growth of agrarian population density. Indeed, the life of agrarian population depends on the soil fertility. Thus, the population density closely attached with their economic level. Generally, the nations without high capital will also reach high density, between 250-400 persons per each square. Such typology is also applied in tropical and subtropical areas, such as Java, Bengali, Eastern China, and Japan. The population densities in such areas become the symbol of world population density (Gelderen, 1974: 22).

In this relation, the high level of population density in Java in the third decade of 19th century brings the attention and statement of the population expert. It was stated that the level of population density for fertile regions in Java is higher than the population density in the most crowded countries. As quoted by Breman (1971: 27) is as follows:

The average level of world population density has reached 250-400 persons, while in Java reached 600 persons per square $\mathrm{km}$. This was caused by the fast growth of population, around $2.5 \%$ per year. As an illustration, Javanese population on 1795 was 3.500 .000 persons, and during 1815 increased to 4.499 .250 peoples. While on 1830 the total Javanese population has increased to 7.054 .833 peoples.

If we analyzed further, actually the Java population tends to disperse. As a proof, in 1815 , the 4.5 peoples of Java and Madura concentrated on fertile regions. In one place, there were 880 peoples, but in another area had only 9 people per square kilometer. The causes are absolutely can be explain economically. (Gelderen, 1974: 9).

Traditionally, the important meaning of a region has always related to the level of soil fertility and the population density. This is because, for the government, such fertile regions are considered as state's economic source and labor source. In the reality, the fertile districts tend to have higher population density rather than the less fertile districts. In Java Island, in particular the fertile districts traditionally have become the residential area and also density population enclave. But overall, the Javanese density on 19th century was around 600 persons per square kilometer (Boeke, 1983: 78):

\section{Table 5.1}

\section{The Poluation Density in Java On 1800 (per square km)}

\begin{tabular}{|l|l|l|}
\hline No & District Name & Density Level \\
\hline 1. & Bandung Highland & 671 \\
\hline 2. & Cirebon Plain & 657 \\
\hline 3. & $\begin{array}{l}\text { South Central Java \& } \\
\text { Serayu Valley }\end{array}$ & 679 \\
\hline $4 \cdot$ & $\begin{array}{l}\text { Bojonegoro Plain and } \\
\text { Surabaya }\end{array}$ & 580 \\
\hline 5. & Malang Highland & 512 \\
\hline
\end{tabular}

Source: Gelderen, J.van, 1974, Tanah dan Penduduk di Indonesia, Jakarta, Bhratara, page 22.

This table can be explained that the level of population density for several fertile districts in Java Island since the early 19th century had showed a very high density. Comparing to the average of word population density at that time had around 250-400 persons per square kilometer (Boeke, 1983: 78). Even in the south Central Java district and Serayu Valley had the 
most density. If Serayu Valley considered as the central district of Banyumas, then it was also classified as high population density, 679 persons per square kilometer (Gelderen, 1974: 22).

The calculation of population density in Serayu Valley at that timecertainly has some error. This is because the high difficulties to conducted population research with right precision. As we know, geographically, this district was highly isolated. Thus, the numbers showed still much estimation. The exact total population is the calculation in 1830. Unfortunately, the total population at that time still counted in form of work unit which called as cacah. Traditionally, cacah is the wok unit that covers of 4-5 man labor (male) which took from the peasant. Sometimes, one family has more than one cacah, but generally, one cacah is more than one family (Peper, 1975: 81, Niel, 1987: 120). Based on the calculation of total population at the early age of colonial in all districts of Banyumas, Banyumas had population around 7,416 cacah (ANRI Banjoemas 11.4, 1830).

The near exact data of total population of Banyumas is the population census which been done by the colonial on 1834. At that time, in Banyumas Residence had 397,685 peoples (ANRI Banjoemas 48, 1834). The number of population was distributed in four districts, Banyumas District with 110,158 populations, Purbalingga with 117,889populations, and Banjarnegara with 52,137 populations. While Purwokerto and Dayaluhur, that districts each had 81,137 populations and 36,152 populations (ANRI Banjoemas 48, 1834, ANRI Banjoemas 20, 1838).

Traditionally, the role of village in Banyumas is not only as economic base for the central government, but also as the center of workforce. The peasant, besides their duty to give half of their crop to the landlord, they are also responsible on various works (Burger, 1962: 97, Hayami \& Kikuichi, 1987: 12). Thus, the fertile and populated district becomes the potential resource, either economic or labor from the peasant. For royal government, the population has a role to provide crop as their tax, compulsory labor, and conscription (Breman, 1971: 13).

The rural population since the reign of monarchy has familiar with the various compulsory labor. Such work, for the rural population is the duty that needs to be done. Essentially, the work relation formation between the populations with traditional leader is very diverse. But, according to Vink (1984: 87), such work is also can be categorized in three formations as follows:

1. Work as tax payment, work for the interest of their leader, so that the people can cultivate the arable land.

2. Work for the community, work together with the other member of community for the interest of all community members.

3. Work for the individual interest, the purpose of this kind of work is to get mutual services or it is expected to get certain rewards, when the time arrived.

Based on the demographic situation, it can be stated that the high population densityislucrativeplaceforthegovernment. This is caused by the district location where traditionally the labour place for the authority interest. As the proof of this statement, at the end of Surakarta reign, Banyumas (1830) had provided at least 2,600 men of forced labour (rodi) for the palace interest (Hugenhollz, 1983: 170). 


\section{Status of Land Ownership}

For the rural peasant, farmland took the first position that is crucial for their life. Traditionally, the member of village community has a certain rights on the land in that village which called the rights of mastering or hak pertuanan (beschikkingsrecht). Such rights is the rights to use on certain arable land, while the outsider from another village can only take the crop within limited time, with the approval from the local resident (Haar, 1950:63). Traditionally, theland ownership concept is different from the West, which aims to the property or eigendom. At the time of Mataram Sultanate, the land located on the kingdom territory shall be governed by the king's officers or authorized party in palace (Pigeaud, 1960: 525).

The authority or officer is not the owner of the land, but politically they have rights over the land in his territory. Theoretically, they have rights and enjoy the crops as stipulated by the prevailing tradition. A part of the land in kingdoms' territory shall be used as religious purposes, and utilize for the interest of village. Besides that, the part of the land has a status as occupation land, known as lungguh or bengkok (Wiradi, 1989: 68).

The origin of rural land comes from the work of pioneering peasants who jointly conduct the land clearing. As the result, the land shall be claim as communal land. If the whole villagers all together work the land clearing for the interest of all resident, then such land will become village land (Meer, 1979: 66). Afterwards, such communal land belongs to villagers and the land tenant (Kroef, 1984: 146). The individual land clearing can be also conducted with the approval of the head of village, as long as there is no breaching of any rights (Haar, 1950: 104).

Before the individual land ownership tendency, the forms of land ownership in rural Java was very varied. However, the most common traditional form is the use rights of communal land. With this system, all the land, either the arable land or the reserve land in the form of forest and bera, overall are under the control of village. The peasant receives the land rights based on the agreement with the members of the village population. In accordance with the customary laws in the population of Java, there is a chance that the form of ownership over the farmland may be exercise for indefinite time. Basically, the rights of ownership of farmland are authorized to the villagers who meet certain requirements; however the land remains as the part of the village communal land. Thus, a person with certain conditions, can use a quite large piece of land continuously, and may delegate the rights over the land to his/her heirs (Vollenhoven, 1918: 512-513).

At the time of Mataram Sultanate, the individual rights of land ownership was already well known by the population, but only in very limited circles. Certainly, there are basic requirements that must be filled to obtain the individual rights, because this right is only held by independent peasant, who are the main residents of the village. They are the founders of the village or their descendants. The founders of the village which is usually a pioneer of the land clearing and their descendants are the village elites that usually called as anak tani or kulina (Meer, 1979: 56). It is suspected that the term of kuli kenceng or kuli kendho is used widely in rural population to call the rights of land ownership in Java, the term derived from the kulina. 
While the status of the land ownership in the area of Banyumas until the early 19th century showed the unequal symptom. The status of communal land ownership is very well known in Purwokerto, Purbalingga, Cilacap, Banjarnegara, Banyumas and the main Banyumas area. However, for the land that owned by the individuals is very difficult to find in the main area of Banyumas (Tauchid, 1952: 124). The status of individual land ownership in the region is generally obtained from generation to generation, which is called the land of yasa, cokrah, pusaka, or the land of turunan (Kroef, 1984: 149).

Theoretically, the term of rights of land ownership refers to the more exact concept, which is closely to the meaning of absolute rights in the modern sense. Of course at that time the villagers who may have the rights were very small, because the prevailing custom requirements. The most basic requirement is the person came from the village founders or the descendants. They can work on their own land or at least interested to work on it. The land rights can be inherited, but if the heir was still too young, then they have to wait until such heir considered as adult or married. As we know, the consequences of the rights of land ownership are paying taxes and doing the compulsory work. If such obligations cannot be implemented, then the rights of land ownership may be revoked. The status of the land ownership is also considered no longer valid, when the owner left the village without mentioned anything over the land. The revocation of the rights can also be performed, if there is no one qualified heir. The handling of such cases is submitted entirely to the head of village or the concerned village official (Kano, 1984: 46).
In fact, either the communal or individual land ownership is still not construe as the absolute property. As we know, in 1656, the Amangkurat I (16451677) issued a statement, that the people in all regions of the kingdom is the resident who does not have any right to any object. All property owned by a resident declared as the belonging of the ruling king (Graaf, 1987: 22-23). This is understandable that in a feudal society, politically the ruling king can claim himself as the land owner in his entire territory, not the absolute individual ownership (Schrieke, 1975: 29).

The change in the status of land ownership was also occurred in Banyumas region, which was originally aimed at the west part of mancanegara kilen region, namely East Priangan region. At the time of Amangkurat I, the region was placed under the direct suzerainty (Graaf, 1986: 123-124). Along with it, the status of the region converted to the pemajekan land or region. The type of pemajekan region was different with the perdikan region in general. The region with such status was led by independent mantri who ruled the free region. The mantri has right to imposed the tax on the population and authorized to determine the type of tribute for the king (Kartohadikoesoemo, 1965: 75).

During the reign of Amangkurat I, turned that the king was done many requisition rights over the land in Banyumas, without regarding the personal rights that still applicable over such land. The king thinks that the residents of Banyumas region who still owns the rights over the farmland, basically only have rights as the land tenant (Schrieke, 1975: 35). As a result of the political change in the land ownership status, then formed a tradition associated with the obligation 
of the land tenant for the next period. The owner of the land rights, who also as tenant, they should submit the half of their gross crops at every time of harvest. This sort of thing is seen as evidence that the farmland was owned by the kingdom. Meanwhile, the position of peasant was the tenant of the land that owned by the ruling kingdom, they used the profit-sharing system (Kartohadikoesoemo, 1965: 35).

As the owner of farmlands, the king gave the right of tenant to the residents, especially for paddy field. In Banyumas, the occupation land (bengkok) has reached about one-fifth part of all arable land, exempted from the tax payment which required by the kingdom. Thus, 4/5 parts of the land were owned by the king that planted and harvested by the peasant with the obligation to handed over the half of their crop. Therefore, it was called as pemaro (Scheltema, 1985: 134).

Although in Banyumas, the change of the land status was occurred, as the result of the kingdom policy, it was almost not change the way of life of peasant. In general, the peasants still think that the production is a means to consume. Still, there is a tendency among them to jointly devour their production (Gelderen, 1981: 19). Thus, they have not doing any economical effort, but they simply are only able to manage the household for their life needs and not managing the business (Wolf, 1985: 3).

Such symptoms are almost distributed equally, as of become the life characteristic of peasant community in Java in general. It is also revealed, that the daily pattern of the peasant who lived until the 19th century is illustrated by Gelderen (1981: 8) as follows:
The resident has simple standard of life, mostly the menu has a large portion of vegetable, the minimum need of clothes. They have a gentle nature, nrimo, have great social feelings. They often do not show her distress and easy going, and less rational.

Based on the description, it may give further insight, that traditionally the life of peasant in rural community has highly dependent on two main points, the agrarian life and the strong social bonds. The balance between two main things is always maintained to achieve a harmonious life. In such conditions, rural communities can achieve a peaceful and romantic life. With a very limited life, they are still trying to establish a harmonious relationship with the natural surroundings. Thus, the principle of life is a motivation for the resident to always be able to conduct the daily work with serenity (Vries, 1972: 12).

\section{Economic System}

To be able to understand the rural economy, we should also see the problems related to the perspective view of peasant. This means, the pattern of economic life of the rural population is closely connected to the issue of organization, production, consumption, ownership status, and their obligations. These issues can affect the trend pattern in their economic life (Gamst, 1981: 10). If so, then to understand the traditional economic system of the peasant in the rural community is a quite complex issue. In general, farmland in Java is a vast plain that have river. From their natural conditions, it is able to create beautiful natural views in the rural areas, which also affects the moral development of peasant to rely on nature (Booth, 1988: 3). 
Considering their dependency on nature, the problem of season is constructed as the cosmos imbalance. According to their view, the season disorder may occur due to their negligence. To keep the balance continuously, then the peasant at certain times establishes ritual ceremonies for each planting season or after harvest in the form of cleaning activity or village ruwatan (Bertling, 1974: 9).

In Banyumas region, such reality brings a wide social impact in the population of peasant. The absorption process of an individual in society occurred, so that the common good should become priority before the individual interest. The social activities are also placed on top of economic activity, so the prestige is deemed more important than the profits (Boeke, 1971: 22). Thus, the ownership of the production instrument is not for the personal purposes, but tended to show the status of the owner. Clearly, that the social value has more important position rather than the economic value (Gelderen, 1981: 9-10).

Based on such fact, the autonomous traditional economic activities in the population is apparent, because they are not followed by the personal impulses. The mutual influences between individuals or individuals with group or individuals with their community are coloring their daily life (Vries, 1972: 12). The rural economic activities besides treats their land traditionally for the food self-sufficiency, they also try to keep the balance between the factors of production with consumption.

The balance related with the living standards that has become a habit in the society. Most members of the community have the perspective, that the pattern of balance must be maintained. Similarly, the available land and the number of people who have to live are not an arbitraries amount. In general, all members of the community are aware of it, so that the balance of life is still under control. Thus, the balance between the total resident with the economic resources can always be maintained (Boeke, 1983: 24). In such connection, the villages can freely define its borders, but for their economic reason, they are not using the farmland more than the necessity for the purpose of their population (Boeke, 1971: 16).

\section{Money Economic Expansion}

At the beginning of the cultuurstelsel system, the economy of the rural population still used close system. The rural communities were highly attached by the traditional bonds, both the village bond and feudal bond. The colonial government was very aware of how strong the two types of bonds, which it was very beneficial to the implementation of cultuurstelsel system. On the basis of these considerations, the colonial policy in the form of cultuurstelsel system was based on the traditional institutions that already existed (Kartodirdjo, 1988: 318). This is a strong indication, which the colonial has predicted that their influence cannot easily absorb into the rural society (Kolff, 1974: 35).

Gradually the influence of the colonial economy is able to touch the lives of population which started with the arising of economic tensions in community. Such conditions occurred, because the populations in rural areas were forced to maintain the balance between the two different demands, the inner demands and the outer demands. In the perspective of socio-economist, since the kingdom times, the population in rural areas was not only as the source of labor (fund of 
power), but also as an economic player (economic agent). As the economic agent, their position is crucial for the attainment of food self-sufficiency. As stated by Wolf (1985: 19), that:

For the peasant, land is an economic unit. Thus, besides the population act as a production unit which helped by many hands, they also has a role as consumption unit that consisting of many mouths. Certainly, the unit is not just feed their members, but also has to give a lot of care.

When the use of forced labor in the plantation sector was no longer effective, then wage employment for the rural population began to open. At first, the available work opportunity of wage labour is as carts towing, firewood porter, and blue-collar workers in the sugar mill as labour (Niel, 1992: 14). The demand of independent labour with certain paid was appeared when the plantations increasingly expanded and the processing factories were established. As a result, the more labor was required. Meanwhile, the recruited workers for compulsory work (gugur gunung) shall not be able to meet for all kinds of jobs. The forced labour served to build the road was no longer possible to be used for plantation and factory, as well as effectively for the organizing transport. This indicated that the use of wage labor is seen as an alternative deemed appropriate (Burger, 1962: 83).

Along with the ongoing developments, the payment of plantation wage (plantloon) was given after the handover of cultuurstelsel crop; this is also seen as a labor exchange system with money in return for the work that has been done. It is also considered as one of the factors that will determine the process of change towards liberation from the bonds of forced labor to contract labor system which based on wages (Burger, 1962: 83). Thus, the independent labor is more seen as an ordinary matter. In such conditions, the pressures of the traditional ruler are no longer an incentive for villagers to do the compulsory work. For them, work in sugar cane plantation or sugar factory gives them financial rewards. This clearly, that the stimulus in form of money is very important to drive the villagers labor (Elson, 1988: 77). Such circumstance continues to grow, so in 1900, the relationship between the population and the employer towards a system that is completely independent. In the system of independent labor, the workforce consisted of daily laborers who are working for 10 hours, from 07.00 until 18.00 (Levert, 1934: 136).

In fact, the available jobs in the sugarcane plantation and sugar mill are not proportional with the number of job seekers. Thisis because the rapid population growth cannot be accommodated in agricultural employment. As a result, the increasing of job seekers faced with the limited job opportunities, so that it can no longer appropriately accommodate the labor fulfillment demand. Such conditions put people in a more dependent position on the colonial (Kolff, 1986: 209-210). If the number of job seeker is greater than the amount of labor required, then this situation shall bring negative impacts. Among other is the existence of the employment agency (broker) whose position became increasingly stronger. Such symptoms are seen as a general description that characterizes the society when people are faced with the limited job opportunities that are not equal with the abundant labour. In this regard, Boeke 
(1983: 98) stated, that:

The position of the labor agency (broker) is becoming increasingly central and important, given that the job seekers cannot deal directly with the employer. Unfortunately, socio-economically the agents cannot relate the two parties. The job seekers consist of residents who are not educated, so they are willing to accept low wages, while the special position is in fact given for the agents.

In such conditions, many rights of job seekers are not protected. Although, the job are obtained on the contract basis, but the existing contracts cannot defend them from the larger power. The workers are powerless against the brokers and business owner. Thus, theoretically the independent labor system should be very profitable for the population, but in reality the freedom to achieve socio-economic ideals even more increase the capitalism exploitation (Furnivall, 1944: 225-226).

The abundance of job seekers is also a case in Banyumas. As proof, during 18951900 , the number of registered job seekers reached around 46,960 people. From such number, not all the job seekers could be absorbed as labour, either on sugarcane plantations and sugar mills. On the sugar cane plantations can only accommodated about 9,505 labors or $18.6 \%$. While the sugar mills can only employed around 10,565 labors or about 20,7\% (Fernando, 1991: 159). Thus, about 60\% of job seekers cannot be accommodated whether in sugarcane plantation and sugar factory as the wage laborers.

In the process of interaction between the job seeker with the colonial which represented by the business owner, frequently clashes were occurred. The emergence of the conflict is a reflection of the difference between the two interests that cannot be resolve. On the one hand, the population interest to live appropriately and on the one side, the interest of the capital owners who strive to get the maximum benefit. Two alternatives to choose are to stay alive as underprivileged peasant, or working on the plantation with the risk of minimum payment and victim of exploitation. Such conditions give the rural population a difficult choice. However, they gradually managed to acquire the balance. The way is with saving and downward adjustment, so that they stay at the limit of minimum needs (Vries, 1972: 17).

The residents who are not accommodated as labour in the sugar cane plantation or sugar mill tried to find another alternative. They strive to meet their needs from a variety of sources of employment that can generate money. For residents, the value of money is extremely important, given that the tax payment, levies and the fulfillment of various needs are measured by money. The craftsmanship and services sector are the alternative that selected by population. The type of craftsmanship among other is the making of coconut oil, coconut sugar, snacks, and other items made for the needs of the local market. Then the services sector is in the form of traditional transportation services, such as transport carriage or dokar which drawn by horses and carts drawn by horses or oxen also becoming an important job. In general, they daily earning is about 28 cents to 35 cents. The special employment for women also began to receive attention, such as drape, batik, and small traders (Fernando, 1991: 165). 
Generally, the craftsmanship and small business sector have difficulty to grow, because the very limited capital. If the business uses small capital, it will reflect the income. They use most of the time to protect their life through the effort and hard work. Meanwhile, during 1885-1890, the population had rough times. This was the crisis impact of the plantation owners which caused by the sereh, the disease that attack sugarcane. To covering the loss, the business owner not only got a low income, but they should paid high taxes. At that time, land tax must be paid f. 42, 48 per bau, whereas the peasant only earned $f$. 25 per bau for the cane planting on their land. Many of plantation and sugar mill labour loss their job, thus it have fatal consequences for the population economy (Furnivall, 1944: 24).

In such conditions, the craftsmanship sector was seen by the residents as the main alternative to sustain their lives. Thus, during 1895-1900, most of the population around the plantation had side job besides the farming, namely the craftsmanship. As proof, it can be observed on the following table:

Table 5.2

\section{Type of Population Work in Banyumas on 1900}

\begin{tabular}{|l|l|l|l|}
\hline No. & Job & Total & Percentage (\%) \\
\hline 1. & Craftsmanship & 25.905 & 58,2 \\
\hline 2. & Transportation & 985 & 1,9 \\
\hline 3. & Plantation labour & 9.505 & 18,6 \\
\hline 4. & Sugar Cane labour & 10.565 & 20,7 \\
\hline
\end{tabular}

Source: Fernando, M.R., 1991,"Javanese Peasants and By-Employment at the Turn of the Century", in Observing Change in Asia, Conford, Beathurst, page 165 .

In 1900, some craftsmanship industry has started to progress. Drape was generally worked by women labour and developed in a quite large scale for trading purposes. This sector can accommodate a workforce of about 6,000 peoples who worked as part time. As a drape labour, they had average income of about 10 cents to 15 cents on each weekday (Fernando, 1991: 168).

Drape sector in Banyumas is also a job that is quite popular. Not less than 5,000 peoples worked as part time during 1900. They earned wages ranging from 5 cents to 15 cents for each day. In general, they worked for the traders and capital owners, whether the Chinese and the indigenous (Fernando, 1991: 168). Generally, this kind of job is only their secondary job. It was meant only to add the family income outside their farms. Thus, the work or trade is only applicable when they have no activities in the field (Vries, 1972: 68-69).

The household craftsmanship, such as palm oil was also developed in Banyumas, involving about 600 families, while the peanut oil occupied by about 3,000 families. The coconut sugar also developed as a family craft industry which was done by rural resident in Banyumas residence. Not less than 400 families were running this type of craft. The making of palm sugar was also known in various places on the Banyumas residence. There were approximately 300 families working as artisan of palm sugar regularly. Other kind of craft done by the rural population was an assortment of snacks made from cassava, soybean, and crackers that were produced in a smaller scale (Fernando, 1991: 163).

It should also be noted here, that the development of the craftsmanship sector in the rural of Banyumas increasingly enriched by the role of women in economic activities, either as artisans, craft workers, as well as small traders. This opened 
the way for the next development. The family energy used to organize household production and the crops by using minor capital (Fernando, 1991: 169).

The atmosphere of rural residents in the period of Banyumas residence. In 1900 has been colored by money as the economic activity. Each person (usually a woman) can bring their crops and handicrafts in rural markets to get a few cents. Each village has a market for once a week. While the small traders that consist of women, selling her wares at store or local market to gain a slight benefit. On the other hand, the rich farmers, generally, used to sell their crops, such as peanuts, coconut, tobacco, and fruits to earn a few hundred cents. The agricultural products and traditional field such as rice, cassava, and pulses are usually accommodated by the middlemen in the local market, which further they shall sell it as the inter-region commodity in the Banyumas Residence and the surrounding areas. In addition, forest products such as bamboo, wood, rattan, usually processed into crafts and household items, which are also the merchandise in local markets (Fernando, 1991: 163).

Such symptoms indicated the peasant abilityto shift the traditional economicsystem to money economic system which has more open system. This could be happen, because the strong motivation among individual peasant to ensure the needs of their family, the reason of insufficient farming. The development in the craftsmanship, small trader, and service sector are the proof, which the capitalist economic system has penetrated into the economic system of the peasant (Hayami \& Kikuichi, 1987: 20-21).

At the end of 1900, in the Banyumas Residence emerged the large scale craftsmanship enterprise that managed more professionally. The drape, batik, coconut oil, coconut sugar and palm sugar were done by the permanent labour. This development was followed by the arising of the traders, both Chinese and indigenous who opened various trading businesses in the local towns to accommodate and sell a variety of crafts which produced by the resident (Fernando, 1991: 164).

The resident with numpang (nonpermanent) status, who is only depends as a craft worker, the family economic situation does not have much hope. They have to survive on low wages, so that they should make an appropriate adjustment to the minimum standard of living. As an illustration, the economic situation of drape and batik labour, only earned 10-15 cents a day, so they had to work hard to protect their family alive. In general, each family consisting of 5-6 members, they can live with 8 cents a day. Thus, from the wages as drape or batik craft worker, they do not have too much spare money. With such money, they can set a budget for the household basic needs as follows:

Table 5.3

Rural Family Budget (Per day in 1900)

\begin{tabular}{|l|l|l|}
\hline No. & Items Name & $\begin{array}{l}\text { Price } \\
\text { (cent) }\end{array}$ \\
\hline 1. & Rice $1,5 \mathrm{~kg} @ 2,5$ cent & 4 \\
\hline 2. & Kerosene & 0,5 \\
\hline 3. & Herbs & 0,5 \\
\hline 4. & Major vegetables & 1 \\
\hline $5 \cdot$ & Additional food & 1 \\
\hline 6. & Tobacco and betel & 0,5 \\
\hline 7. & Cooking oil and firewood & 0,5 \\
\hline Total & 8,0 & \\
\hline
\end{tabular}

Source : Penders, C.L.M (ed.), 1977, Indonesia: Selected Documents on Colonialism and Nationalism 1830-1942, St. Lucia, University of Queensland Press, page 55 .

The daily spending still have to be added by tax payment, other charges, and social 
expenditures. The budget for incidental purposes, such as organizing a family party, buying clothes and other social necessities also required a lot of funds. Usually to covers the incidental need, they not took it from their saving. But the most common way is by selling their crops or livestock. Even if it is inevitable, they shall lending money to the capital owner with high interest (Penders, 1977: 53).

For the less fortunate residents, the daily expenses can still be reduced by doing downward adjustments. Such family still can survive only by 3 cents to 4 cents per day, for average family members that consist of 4 to 5 peoples. Meanwhile, for incidental needs, they can work as farm labour, craft workers or other jobs with low wages. The farm labour is irregular and seasonal job whether at the paddy planting or the crop season. In exchange for the work, they earned a daily wage. Usually they get wage from the planting season, while profit-sharing is obtained if they work during the crops season (Scheltema, 1985: 380).

The farm labour family has forced to live below the poverty line. For more details, generally the family under the minimum living standards prioritizes their daily family budget as follows:

\section{Table 5.4}

\section{Rural Family Minimum Daily} Budget in 1900

\begin{tabular}{|l|l|l|}
\hline No. & Items Name & Price (cent) \\
\hline 1. & Rice & $2,5-3,0$ \\
\hline 2. & Kerosene & 0,24 \\
\hline 3. & Herbs & 0,24 \\
\hline 4. & Tobacco & 0,24 \\
\hline 5. & Betel & 0,24 \\
\hline
\end{tabular}

Source: Penders, C.L.M. (ed.), 1977, Indonesia: Selected Documents on Colonials and Nationalism, St. Lucia, University Queensland Press, page 56.
Theoretically, to see the level of prosperity of the population in an agrarian area population, then their income should be converted into the prevailing price of rice at that time. As we know, a craft worker earned on average about 10-15 cents per day. If the price of rice was about 2.5 cents per kilogram, the average daily income shall between 3.2 to 4.6 kilograms of rice. Thus, the average income of craft worker each year ranged from 1,152 to 1,728 kilograms of rice. If the average family has 5 to 6 peoples, then the average income of each person in each year ranged from 193 to 230 kilograms of rice. Based on the population living standards in rural areas, the family with such income is at the poverty level or below the poverty line (Sajogyo, 1978: 8). Further stated, that:

Because the rice is a primary need, then the poverty line is often measured by the demand of rice. This method is used based on the concept of rice equivalent expenditure. For rural households have income below $180 \mathrm{~kg}$ for each person per year, it is very poor, and the earning between 180-240 kg for each person per year is poor, while the income of $240-320 \mathrm{~kg}$ for each person per year is a middle class group. To be able to survive the villagers require $10-15 \mathrm{~kg}$ of rice, whereas for other basic needs adequately takes 5-10 $\mathrm{kg}$ of rice for each person per month (Sajogyo, 1978,"Lapisan Masyarakat yang Paling Lemah di Pedesaan Jawa", Prisma, No. 6, page 8).

Of course for the rich people, relatively have better economic conditions. The farm labour (kuli kenceng) depends on a large farmland, or the resident who works as labour on sugarcane plantations and sugar 
mills turned out that they have a higher standard of living. The plantation workers who have income of about 16 to 25 cents a day, is able to support his family properly. With the price of rice is about 2.5 cents per kilogram, so the wages can generate $1,683^{-}$ 2,880 kilograms of rice in per year. If the average family has 5-6 members, then each person can be supported by income of around 336-536 kilograms of rice per year. With such income, then the family of sugar plantation labour is categorized as wellenough level. This is because the adequate living standard is the earning of 240-320 kilograms of rice for each person per year (Sajogyo, 1978: 8).

For peasants in rural areas who have entered the money economic system, have to face unavoidable risks. They cannot be protected again from a new uncertainty, which is caused by the development of market economy (Scott, 1976: 87). The artisans, small trader, farmer, and farm labour are required to meet the needs of their family life; sometimes they trapped by the debts with the Chinese middlemen and moneylenders who give high rate of interest. In general, they are victims of the money economic system, because they receiving the down-payment and contract which is essentially used as a binding by the investors to earn higher profits (Laanen, 1988: 336).

In Banyumas Residence, what was happening is not much different from the other area. The need for money especially to meet the basic needs felt very urgent and difficult to obtain. The most urgency is the needs for living expenditures, paying taxes, obtaining a variety of consumer goods, such as clothing, a variety of social needs in the form of a family party and the donation. Because the narrow rural economy, the peasant cannot obtain anything they needed, if they are not expanding their relationship network with the owners of private capital. On such way, they can obtain the cash in a relatively short time. The credit period is usually tailored according to the needs of its business and usually associated with the harvest time. Therefore, if the harvest failed, it should be fatal for their economic life (Gelderen, 1981: 33-34).

The interaction between rural communities is increasingly widespread, along with the increasing loan association which is the typical of the money economic system. The credit agreements and debts cover almost all aspects of business life in the rural areas. Such conditions provide opportunities for the development of a very extensive network of lending money that is managed by an individual, whether conducted by the Chinese, Arab, and rich indigenous with high interest. Even the Dutch people are often also involved in such activities. This sort of thing is usually done through the leasing of farmland that owned by the local residents for plantation purposes. The payment is made based on credit extended or voorschot. The owner of sugarcane and other plantations always pay the rent in cash. With the model of such payments, the peasant is increasingly dependent on business owner in order to earn money. The bad tendency of peasant is always spent the rent money before their farmland used by the tenant. Thus, they are forced to make a new lease agreement for the next year (Gelderen, 1981: 33-34).

Outside the plantation sector, the peasant in Banyumas usually also lease their farmland to earned the money. If with 
the lease, they are not also earned money in sufficient quantities, then they have to sell the land. In general, the peasants who become victims of loan sharks experienced a very serious economic difficulty, because they have to repay the loan with interest that ranging from $100 \%$ to $300 \%$ per year (Haar, 1950: 76).

The involvement of the Banyumas rural population in the money economic system is growing rapidly. Actually, the society systems need more guidance to rescue them from the harmful practice of financial transactions. For the colonial, such condition is considered a perfect moment to establish a formal financial institution. On the basis of consideration to guide the community in monetization, then in 1895 in Banyumas Residence for the first time, the colonial was established a bank called Hulp Spaar-en Landbouwcredietbank. The figure who had such idea is Aria Wiraatmadja, who at that time served as Regent of Purwokerto District. The idea was supported by the local colonial official (Tijdschrift voor het Binnenlandsch Bestuur, XI, 1898: 9).

As the name implies, the bank engaged in money lending services, savings and agricultural credit. As a financial institution, the bank was certainly has to make a profit. To achieve that goal, the bank set a maximum interest rules. The interest rate for the saver shall be given $6 \%$ per year, whereas in the form of cash loans shall be bear $12 \%$ per year. While, the loans in form of goods (rice) shall be subjected $25 \%$ interest for a half year period (Tijdschrift voor het Binnenlandsch Bestuur, XI, 1898: 9).

In observing the rules on bank interest, apparently it was too high for agricultural loan. This is cannot be separate from the purpose of bank establishment, which is to make a profit. In fact, not all of resident can be their customer, the bank given the specific requirements that must be filled. Thus, only certain groups of people can obtain the services of the financial institution. In general, a group of kuli kenceng, village officials, indigenous groups who occupied the colonial bureaucracy, Chinese merchants, and the Europeans (Tijdschrift voor het Binnenlandsch Bestuur, XIX, 1900: 209). In other words it can be stated, that the number of customers who are involved in bank activities covers only a limited group of people.

However, the bank has experiencing a quite good development. It can be observed from the increasing number of customers and the higher turnover of the bank. During 1897, the bank has been given loans to 77 people from 12 villages, with a total loan f. 1,677. A year later (1898) the money loan has been given to 7 people with the amount f. 300 for each person, while the other 148 loans, including the small loans has been given to a number of people who came from 13 villages, with total f. 2,432. For the next year (1899), the lended money has reached f. 10,630.975 that were given to 327 customers (Tijdschrift voor het Binnenlandsch Bestuur, XIX, 1900: 209). Meanwhile in 1900, the bank turnover for the lending sector has reached f. 14,865.26 (Tijdschrift voor het Binnenlandsch Bertuur, XI, 1901: 212).

For the saving services, in 1899, the bank has recruited 94 customers. The total saving reached approximately $f$. $3,482.26$. However, the deposit has slow development. At that time, the bank only had obtained 6 Dutch costumers and 9 indigenous customers. The total nominal of deposit was f. 8,038.76, as of the total 
saving reached f. 11,521.02. As we know, for the agricultural credit service sector had providing period of loan for half year, with interest rate $25 \%$. In the first year (1898) has lent 620.27 pikul (equal with 62.5 kilogram) to 18 farmer groups, consisting of 417 persons. Then in 1899, the bank issued 722.50 pikul paddies which have been given to 17 farmer groups. The next development was more delighted. In 1900, number of lend paddies was increased to 1,000 pikul for the population from several villages (Tijsdschrift voor het Binnenlandsch Bestuur, XIX, 1900: 212).

\section{Side Effect of Money Economic}

With the kind of such development, stated that the money economic system in Banyumas has spread more widely. People's lives became very dependent on the currency, which not only serves as an instrument of exchange and means of payment. The currency also becomes the measure of prosperity and symbol of social status for the people in that area.

In the 1880 s period, the private capital was invested in a large scale on sugar cane plantation and sugar mills. At that time, there was the tendency for business owner to establish a direct contact with the villagers in an attempt to gain land and labor. With this trend, the Western elements became absorbed in the rural, not only geographically, but also structurally. With the direct contact between the business owner and the rural population, the structure of the Java community more and more mixed. As a result, gradually emerge the spirit of individualism in society. Such symptoms increasingly widespread, as the employers are always looking for the new areas to expand their business (Burger, 1983: 11-12).
Meanwhile the expansion of the plantation, especially the private sugar cane plantations and sugar mills were deeply affected by the demands of paid labor and the use of farmland through the contract system. Such new developments also affect the shift in tenure from the communal ownership to individual ownership. This land tenure leads to absolute ownership properties and can be inherited. In Banyumas, land with such mastery status called yasa, cokrah, pusaka or turunan. Along with the occurred change process, gradually the system of land tax and other charged taxes must be paid in cash (Burger, 1983: 12, Aass, 1984: 126).

The tendency of individual land tenure has grown rapidly, because the chances of handing over the land from the narrow land peasant to the large land peasant became very wide open. The transfer of such rights may occur, given that the peasant is stuck in the money economic arena. For them, money is very important to meet the needs of daily living (Breman, 1971: 44-45, Lyon, 1984: 168).

In Banyumas Residence, the process of transfer of rights over the land can be conducted through various forms of buying and selling. At the very least, the residents use three kinds of purchase agreement, which are selling off, pledge to sell, and annual sell. The three kinds of purchase according to the terms prevailing in the population of Banyumas are ngedol dongkelan or ngedol plas, ngedol sende, and ngedol tahunan (Haar, 1950: 76).

Selling off (ngedol dongkelan or plas) is the delivery of a piece of land to another person with the agreed sum of money, on the condition that the rights over the land are also transfer to the buyer. Then the 
pledge to sell (ngedol sende) is the delivery of a piece of land with the payment of a sum of money or goods in cash, but the landowner still owns the rights over the land, if he/she is able to return the received payment. Meanwhile, the annual sell (annual ngedol) is the delivery of a piece of land to another person for several years in accordance with the agreement within the payment of money. Upon maturity, such land shall be returned to the landowner without applying any terms and conditions (Hakim, 1965: 6, 20, and 61).

The increasing numbers of the transfer of land rights, showed a strong indication that the peasant family environment experienced an imbalance of their income and expenditure. To overcome this, they often engaged in money lending transaction with high interest rates. As a result, they are still unbalance, and their financial got worse. This kind of problem is seen as a typical symptom of the Western economic system absorption, in the advances form of cash economic traffic that hit the rural population. Such symptoms are often referred to as the power of "evil" of the money economy (Renneft, 1974: x).

If we observed, the changes that occurred in rural communities are very complex. Essentially, the changes in farmland tenure sector as the main source of agricultural economic elements, this is very influencing the changes on other elements in society. This is because; there are elements in society that are related to each other. Thus, if one element changes then the other elements shall also shift to adjust with the previous changed elements. In this regard, the social structure and system of labor relations as part of the elements of social organization are also experienced the fundamental changes. The transfer of land ownership was followed by the emergence of landless peasant in large numbers, putting the peasant who has the land rights in a very important position. Therefore, the determination of labor is also shifting from the authority of the village head to the responsibility of farmland ruler (Temple, 1989: 86). The labour (kuli) groups who hold the land rights has major role in labor demand, but because the absence of changes in the production process then the main decision of labor and equipment is established by the village social obligations. Everyone has the right to take part in the production process, while the crop distribution is determined by the social structures that exist (Jaspan, 1961: 13).

Generally, the rights owner over the farmland is acted as community leaders which his position becomes increasingly strong. In the environment of the rural population, they are no longer called as sikep peasant, but a kuli. The term of kuli referred to the obligation of land owner on the social obligation to perform work for the benefit of the village. In Banyumas Residence, the kuli terms related to such workload called as kuli kerig. In addition, the term kuli is also closely associated with farmland owner called kulen (Kano, 1984: 50). Such kuli groups may enjoy most of the crops of their farmland, thus it encouraging the process of land tenure concentration to the hands of this group (Jaspan, 1961: 13).

They may be divided into two groups, in the terms of the land size owned. The two groups are the first called as kuli kenceng and the second as kuli kendho. The first group has farmland at least one bau (1 bau equal with $7,000-7,400$ meters), while the 
second group has less size of farmland from such size (Tjondronegoro \& Wiradi, 1984: 44-45). What happened in Banyumas also showed the same symptoms. According to the people in that area, the kuli kenceng is more popular with the terms as kuli gladak, kuli baku, or kuli kuat. While, the kuli kendho called as kuli cilik or kuli rempo (Haar, 1950: 74).

The group of landless agricultural usually referred to as numpang or bujang, which is the largest group in rural communities. They live under severe economic pressure. To overcome these problems, they usually work as wage labour in the sugar cane plantation or sugar mill (Aass, 1984: 126). Working as wage labour is based on a rational work contract system which driven by the intensive working relationship (Cahyono, 1991: 10).

Such reality indicates, that population in rural areas have been involved with wider network relationship. Thus, further conversion of the shift of land ownership and the development of wage labor has brought a very broad impact for the social and economic life of rural communities. In turn, it raised the new phenomena in their lives such as the ongoing process of defeudalization (Onghokham, 1984: 24, Suhardi, 1992: 20).

The economic changes in the rural population, at first were an individual emancipation to free themselves from external pressures. This brings the disintegration of transitional society bonds. The feudal bonds gradually detached from the public life and replaced by the individualism (Leirissa, 1985: 10-11). The societies are divided into groups that still rely on rights ownership over the land, which is called the social structure. Social structure in the form of status groups was essentially formed based on the acquisition of farmland rights. They can be grouped in three categories, namely: The First, the landowner group of paddy field, house, and backyard. This group is a leading group called the kuli kenceng. The Second, the group that owns the house, paddy field and backyard with size less of one bau. They referred to as kuli setengah kenceng or kuli kendho. The Third, the group of mondok or numpang, the residents who own a house, but do not have their own paddy field and backyard. The life of this group is very dependent with the kuli kenceng (Scheltema, 1985: 382).

In general, the group of kuli kenceng consists of the village official who is able to maintain their control on large areas of farmland (Niel, 1992: 182). In order to maintain that position, they usually claimed to be the village founders or their descendants (Leiressa, 1985: 10). As the founder of the village or their descendants, they monopolize the official village position and entitled to occupation land (bengkok) and also entitled to the service work from the villagers. Thus, this group is the uppermost layer in the village, while the other population occupied the layer below (Onghokham, 1984: 24, Kroef, 1984: 160161).

Meanwhile, the noble (priyayi) group, such as the pangreh praja (civil servant) is not included in the village social layer, even though they lived in the village. The foreigners also regarded as an outsider, although they have their own house and backyard in the village. Other outside group of people is the newcomer who is considered as the outsider for some times until they meet the necessary requirements 
(Ranneft, 1974: xiii). Along with the ongoing development, the content coverage in the social structure of communities in Banyumas became increasingly complex. The social pattern structure actually is not changed too much, but the existence groups in it are becoming increasingly varied. For the details, Ter Haar (1950: 70), stated as follows:

1. Kuli gladag or kuli kuat, a group of population who own a house, backyard, and paddy field with size of one bau or more.

2. Kuli cilik or kuli rempo, a group of population who own a house, backyard, and paddy field with size less than one bau.

3. Lindung, the resident who has their own house and backyard, but does not have any paddy field.

4. Pondok tempel, a group of population that has no arable land (paddy field), but has their own house which located in other people's land.

5. Pondok ringku, a group of population without arable land and house. They lived together with kuli gladag.

6. Rayat, people who live with kuli's family and all their life need covered by such kuli.

Out of the division, it appears that the first and the second group are the development of sikep group. While from the third to the sixth group are the fractions of numpang. In the reality, each status group carried out various obligations, in accordance with their position. The gladag labour group certainly has the most obligations, as well as a villager who have most farmland. The obligations that applied on the early 2oth century may be grouped into three categories. The third obligation is: The First, the obligation in the real meaning, such as pancen, patrolling or ronda, and kerigan. The Second, janggolan obligation is a duty of labour (kuli) to give their crops for the village interest. In fact, the rice of janggolan is the right of village head. The Third, social obligations, sambatan and mutual aid aimed to help fellow villagers (Ranneft, 1974: xiii).

Based on the condition of society in terms of social structure, it can be stated, that the colonial intervention in the labor sector and the use of farmland for plantation purposes has led to a shift in the social structure in the Banyumas. The change has weakened the traditional horizontal social class village formed based on ownership rights over the land and communal solidarity (Kroef, 1984: 159). Thus, it can be resulted, that the social structure is closely related to the rights and obligations of the villagers. The outline is: The First, the main group of villagers, those who have cultivated land, backyard and home. Some of these groups served as official village or those who feel as the descendant of the founder of the village. As village official, besides their own land, they also gain tanah bengkok or the occupation land which every village has various different sizes. However, the most common occupation land has average 10 bau for village head, 6 bau for carik, 2 bau for kepala dukuh or wewengkon (equal with the head of several neighborhoods). Meanwhile, for the lower positions such as village police, kebayan, and kayim each deserve 1 bau of occupation land. The Second, a group of villagers who have limited communal obligations. They are lindung or indung peasant. The Third, the groups of villagers who do not have any communal obligation. They consist of 
mondok or numpang peasant. Their position is sharecroppers or stay in peasant and work for the landlord (Kroef, 1984: 159).

In a next development, the position of the first layer gradually shifted due to population pressures and other economic influences. They are downgraded, so the grassroots population level is increasing. In some cases, it appears that lindung peasant also has a piece of farmland, but they do not have any backyard. In Banyumas Residence, this group is often called as gundul or bald peasant (Kroef, 1984: 159). The last category is the mondok or numpang, this group tends to develop. This is happen because the increasing of the development process in land ownership among the rural population. Thus, the social structure of the society shows as pyramid. From the illustration seems clear, that the peasant in the rural communities in Banyumas arranged in layers based on tenure rights over farmland. With the development of money economic system in the peasant population, then the available social structure is not fully able to guarantee the welfare of the population.

When the economic system that actually has grown in society in the 20th century, there is indication that the relationship between the prosperity with the ownership rights over the land are more loose. This is in line with the money economic expansion in rural areas was encouraged the population to pursue other business outside the farming. The symptoms can be evidenced by the increasing income average of the traders and indigenous artisan who earned more rather than the land owners and village officials (Husken \& White, 1989: 22-23).

\section{Conclusion}

The continued development of the independent labour system and the widespread of money economic system in the rural area, are not only disrupted the traditional structural foundation, but also urge the indigenous elites in a less decisive role. Along with these developments, the individualization emerged in society that caused by the loosening of traditional bonds, either vertical (feudal bonds) and horizontal (rural bonds). The bonds became deteriorate, so the primordial society shifted into a more rational society (Abdullah \& Leeden, 1986: 14).

Thestructuraldifferentiationincreasingly grows with the creation of new roles that are emerging and replacing the traditional roles. In this regard, the colonial policy is also seen to have a considerable role. The colonial was gradually improving the government administration. The legal process was rational, to achieve the standard size of government bureaucracy in accordance to West standards. This resulted in the decline of traditional political institutions that only serves as a tool of colonial bureaucracy that no longer autonomous, but under the colonial full control (Day, 1904: 159).

The deep impact of the widespread of money economic system, defeudalism process, and destructulization are the shock values in rural communities. This may happen, because the emergence of uncertainty when facing the change situation. The widespread application of money economic system affected the peasant who was more not protected. For the rural population, such condition dislocated the value of the village and other traditional institutions. At the same time, 
the unrest population attempted to find new protector. The weakening support and loyalty of the population for the traditional formal leaders, it is caused by this group support in economic and administrative process.

The village head remains a major figure that has authority in the village. In many aspects, he appeared as a village representative, even though he has different purpose with his people (Scott, 1976: 87). Accordingly, there is loyalty shift in rural population from traditional authorities to the new elite. They are independent scholars or ulama who are not directly involved with the colonial bureaucracy networks. Actually, the term of ulama is a symbol of free religious elite that is solely devoted to the religious science and eschews from political affairs (colonial bureaucracy). In general, they consist of the pilgrims (haji) and clerics (kyai) that practice their knowledge through Islamic boarding school and the establishment of Sufi Orders (Dhofier, 1982: 55).

\section{REFERENCES}

ANRIBanjoemas48.(1834).Administratief Verslag de Residentie Banjoemas.

ANRI Banjoemas 11.4. (1830). Register van Residentie Banjoemas.

ANRI Banjoemas 20. (1838). Statistiek der Residentie Banjoemas 1838.

"Uitbreiding van den Spoorwegbow op Java”. (1898). Tijdschrift voor Nederlandsch

Indie, Vol. I, Groningen, De Erven C.M. van Bolhuis.

Archift. (1900). in Tijdschrift voor het Binnenlandsch Bestuur. Vol. XII, Batavia, Kalft \& Co.
Bleeker, P. (1901). Fragmenten eener Reis over Java. Tijdschrif $\mathrm{t}$ voor Nederlandsch

Indie, II. Groningen. De Erven C.M. van Bolhuis.

Cahyono, R.E.(1991).Transformasi Petani Menjadi Buruh Industri Perkebunan: Studi Kasus Karesidenan Pakalongan 1830 - 1870. Prisma, No. 11, Jakarta, LP3ES.

Husken, F. \& White, B. (1989). Ekonomi Politik Pembangunan dan Struktur Agraria di Jawa. Prisma, No. 4. Jakarta: LP3ES.

Meer, Van Setten van der. (1979). Sawah Cultivation Ancient Java Aspects of Development during the IndoJavanese Period 5th to 15th Century. Oriental Monograph Series, No. 22, Canberra.

Sajogyo. (1978). Lapisan Masyarakat yang Paling Lemah di Pedesaan Jawa. Prisma, No. 6, Jakarta: LP3ES.

Suhardi. (1992). Masuknya Politik Kolonial di Pedesaan dan Pengaruhnya terhadap Kondisi Sosial Ekonomi Petani Desa. Sejarah, No. 2, Jakarta, Gramedia.

Suryo, D. (1991). Kesadaran Sejarah: Sebuah Tinjauan. Makalah, Surakarta, Seminar Kesadaran Sejarah UNS.

Temple, G. P. (1989). Mundurnya Involusi Pertanian. Prisma, No. 4, Jakarta, $\mathrm{LP}_{3} \mathrm{ES}$.

"Varia". (1900). in Tijdschrift voor het Binnenlandsch Bestuur. Vol. XIX, Batavia. Kalft \& Co.

"Verde Jaarverslag van de Poerwokertosche Hulp-Spaar-Landbouwcredietbank over

1900", 1901, in Tijdschrift voor het Binnenlandsch Bestuur, XI, Batavia, Kalft \& Co. 
"Welke Inkomsten trekt Java uit de Suikerkultuur". (1900). in Tijdschrift voor

Binnenlandsch Bestuur. VII. Batavia, Kalft \& Co. Books

Aass, S. (1984). Relevansi Teori Makro Chayanov untuk Kasus Pulau Jawa”, dalam Tjondronegoro, S.M.P., \& Wiradi, G.,(ed.).DuaAbadPenguasaan Tanah: Pola Penguasaan Tanah dari Masa ke Masa. Jakarta: Gramedia.

Bell, F.H. (1978). Teaching and Learning Matematica in Secondary School, Iowa, Wn.C. Brown Co. Publisher.

Boeke, J.H. (1971). Batas-Batas dari Masyarakat Pedesaan. Jakarta: Bhratara.

Boeke, J.H. (1983). Prakapitalisme di Asia. Jakarta: Sinar Harapan.

Booth, A. (1988). "Tinjauan Sejarah Perkembangan Irigasi Indonesia pada Masa sebelum Kemerdekaan”, dalam Pasandaran, E. \& Taylor, D.C.(ed.), Irigasi:Kelembagaan dan Ekonomi. Jakarta: Yayasan Obor Indonesia.

Breman, J. (1971). Jawa: Pertumbuhan Penduduk dan Struktur Demografis. Jakarta: Bhratara.

Breman, J. (1986). Penguasaan Tanah dan Tenaga Kerja Jawa di Masa Kolonial, Jakarta: LP3ES.

Bertling, C. Tj. (1974). Pendeta Tanah di Indonesia. Jakarta: Bhratara.

Burger, D.H. (1962). Sejarah Ekonomi Indonesia dari Segi Sosiologi Sampai Akhir Abad XIX. Jakarta: Pradnyaparamita.

Burger, D.H. (1983). PerubahanPerubahan Struktur dalam Masyarakat Jawa. Jakarta: Bhratara.

Elson, R.E. (1988). "Kemiskinan dan Kemakmuran Kaum Tani pada masa Siatem Tanam Paksa di Pulau Jawa” in
Booth, A., at. al (ed.). Sejarah Ekonomi Indonesia. Jakarta: LP3ES.

Fernando, M.R. (1991). Javanese Peasant and By-Employment at the Turn of the Century. Cranford: Bathurst.

Furnivall, J.S. (1944). Netherlands India: A Study of Plural Economy. Cambrigde: At the University Press.

Gamst, F.C. (1981). Peasant in Complex Society. New York: Renehart \& Winston Inc.

Gelderen, J, van, at. al. (1974). Tanah dan Penduduk di Indonesia. Jakarta: Bhratara.

Gelderen,J,van, at.al.(1981).IlmuEkonomi Jajahan Daerah Khatulistiwa. Jakarta: Bhratara.

Graaf, H.J. de. (1986). Puncak Kekuasaan Mataram: Politik Ekspansi Sultan Agung. Jakarta, Grafiti Pers.

Graaf, H. J. de. (1987). Disintegrasi Mataram di bawah Amangkurat I. Jakarta: Grafiti Pers,

Haar, B. Ter. (1950). Verzamelde Geschriften. Djakarta: Noordhoff Kolff. N.V.

Haar, B. Ter. (1979). Beginselen en Stelsel van het Adatrecht. Jakarta: Pradnyaparamita.

Hakim, S. A. (1965). Djual Lepas, Djual Gadai, dan Djual Tahunan. Jakarta: Bulan Bintang.

Hayami, Y., \& Kikuichi, M. (1981). Dilema Ekonomi Desa: Suatu Pendekatan Ekonomi terhadap Perubahan Kerlembaga di Asia. Jakarta: Yayasan Obor Indonesia.

Hugenholtz, W. R. (1983), "Taxes and Society: Regional Differentces in Central Java around 1830”, dalam Kartodirdjo, S. (ed.).Agrarian History, I. Yogyakarta: Gadjah Mada University Press. 
Kartodirdjo, S. (1988). Pengantar Sejarah Indonesia Baru 1500-190o: Dari Emporium sampai Imperium. Jakarta: Gramedia.

Jaspan. (1961). Social Stratification and Social Mobility in Indonesia. Jakarta: Gunung Agung.

Kano, H. (1984). "Sistem Pemilikan Tanah dan Msyarakat Desa di Jawa abad XIX”, dalam Tjondronegoro, S.M.P. \& Wiradi, G.(ed.). Dua Abad Penguasaan Tanah: Pola Penguasaan Tanah Pertanian di Jawa dari Masa ke Masa. Jakarta: Yayasan Obor Indonesia.

Kartohadikoesoemo. (1965). Desa. Bandung, Sumur Bandung.

Kolff, G.H., van der. (1986). "Sejarah Hubungan Tenaga Kerja di Suatu Daerah Terpencil di Pulau Jawa dalam Hubungannya dengan Budidaya Tanaman Padi”, dalam Sajogyo \& Collier, W.L., (ed.). Budidaya Padi di Pulau Jawa. Jakarta: Yayasan Obor Indonesia.

Kolff, G.H., van der. (1974). Ekonomi Asli dan Asing: Sama dan Berlainan. Jakarta: Bhratara.

Kroef. (1989). "Penguasaan Tanah dan Struktur Sosial di Pedesaan Jawa", dalam Tjondronegoro, S.M.P.\& Wiradi, G.(ed.). Dua Abad Penguasaan Tanah: Pola Penguasaan Tanah di Jawa dari Masa ke Masa. Jakarta, Yayasan Obor Indonesia.

Laanen, J.T.M. van, "Di antara Javansche Bank dan Ceti-ceti Cina: Perbankan dan Kredit di Indonesia pada Zaman Kolonial”, dalam Booth, A., at.al. (ed.), Sejarah Ekonomi Indonesia. Jakarta: LP3ES.

Leirissa, R.Z. (1985). Sejarah Masyarakat Indonesia 1900-1950. Jakarta: Akademika Pressindo.
Levert, P.H. (1934). Inheemsche Arbeid in Java Suikerindustrie. Wageningen, J.A. Honing.

Lyon, M.L. (1984). "Dasar-dasar Konflik di Daerah Pedesaan Jawa", dalam Tjondronegoro, S.M.P.\& Wiradi, G., (ed.). Dua Abad Penguasaan Tanah: Pola Penguasaan Tanah Pertanian di Jawa dari Masa ke Masa. Jakarta: Yayasan Obor Indonesia.

Niel,R.V.(1992).JavaundertheCultivation System: Colectied Writings. Leiden, KITLV Press.

Pender, C.L.M., (ed.). (1977). Indonesia: Selected Documents on Colonials and Nasionalism 1830-1945. St. Lucia, University of Queensland Press.

Peper, B. (1975). Pertumbuhan Penduduk Jawa 180o-1850. Jakarta, Bhratara.

Pigeaud,T.H.(1960).Javain the Fourtienth Century. Nijhoof: The Hague.

Onghokham. (19840. "Perubahan Sosial di Madiun selama Abad XIX: Pajak dan Pengaruhnya terhadap Penguasaan Tanah”, dalam Tjondronegoro, S.M.P.\& Wiradi, G. (ed.). Dua Abad Penguasaan Tanah: Pola Penguasaan Tanah Pertanian di Jawa dari Masa ke Masa. Jakarta, Yayasan Obor Indonesia.

Pauwert, M.J., van der. (1977). "Memori Residen Banyumas 24 Oktober 1925”, dalam Kartodirdjo (ed.). Memori Serah Jabatan 1921-1930 Jawa Tengah. Jakarta: Arsip Nasional Republik Indonesia.

Ranneft, J.W.M. (1974). Laporan-laporan Desa. Jakarta: Arsip Nasional Republik Indonesia.

Scheltema, A.M.P.A. (1985). Bagi Hasil di Hindia Belanda. Jakarta: Yayasan Obor Indonesia.

Schrieke, B.J.O. (1975). Sedikit Uraian tentang Pranata Perdikan. Jakarta: Bhratara. 
Tauchid, M. (1952). Masalah Agraria. Vries, E.de. (1972). Masalah-Masalah Jakarta: Tjakrawala. Petani Jawa. Jakarta: Bhratara.

Tjondronegoro, S.M.P. Wiradi, G. (1984). Wiradi, G. (1989). Penguasaan Tanah Dua Abad Penguasaan Tanah. Jakarta: Obor. dalam Perspektif Transformasi Struktural. Seri Iptek dan

Vink, G.J. (1984). Dasar-dasar Usha Tani Industrialisasi. Surakarta: Lembaga di Indonesia. Jakarta: Yayasan Obor Indonesia.

Penelitian Universitas Muhammadiyah Surakarta.

Vollenhoven, C.van. (1918). Het Adatrecht Wolf, E.R. (1985). Peasents: Foundation van Nederlandsch Indie. Leiden: F.J. of Modern Anthropology Series. Brill.

Englewood: Prentice Hall Inc. 